\title{
Jämförelser med djurvärlden kan ge stereotyp bild av kön i skolan
}

Ulrika Bossér

Det kan finnas problem med att utgå från djurvärlden för att undervisa om människans sexualitet. En ny studie har undersökt hur föreställningar om manligt och kvinnligt kan komma till uttryck i naturkunskapsundervisningen. Bilden som förmedlas är att sexualitet handlar om reproduktion och att manligt och kvinnligt är varandras motsatser.

Kulturella föreställningar om manlighet, kvinnlighet och sexualitet utgår ofta från biologiska skillnader mellan könen. Forskning visar också att människor ofta ser biologiska förklaringar till skillnader mellan män och kvinnor som mer betydelsefulla än andra förklaringar. De biologiska budskapen i skolans undervisning om vad som är manligt och kvinnligt har därför betydelse för vilka möjligheter och begränsningar elever möter när de utvecklar sin självbild. Forskaren Auli Arvola Orlander vid Stockholms universitet har undersökt hur föreställningar om manlighet och kvinnlighet kan förmedlas genom undervisningen i naturkunskap [1].

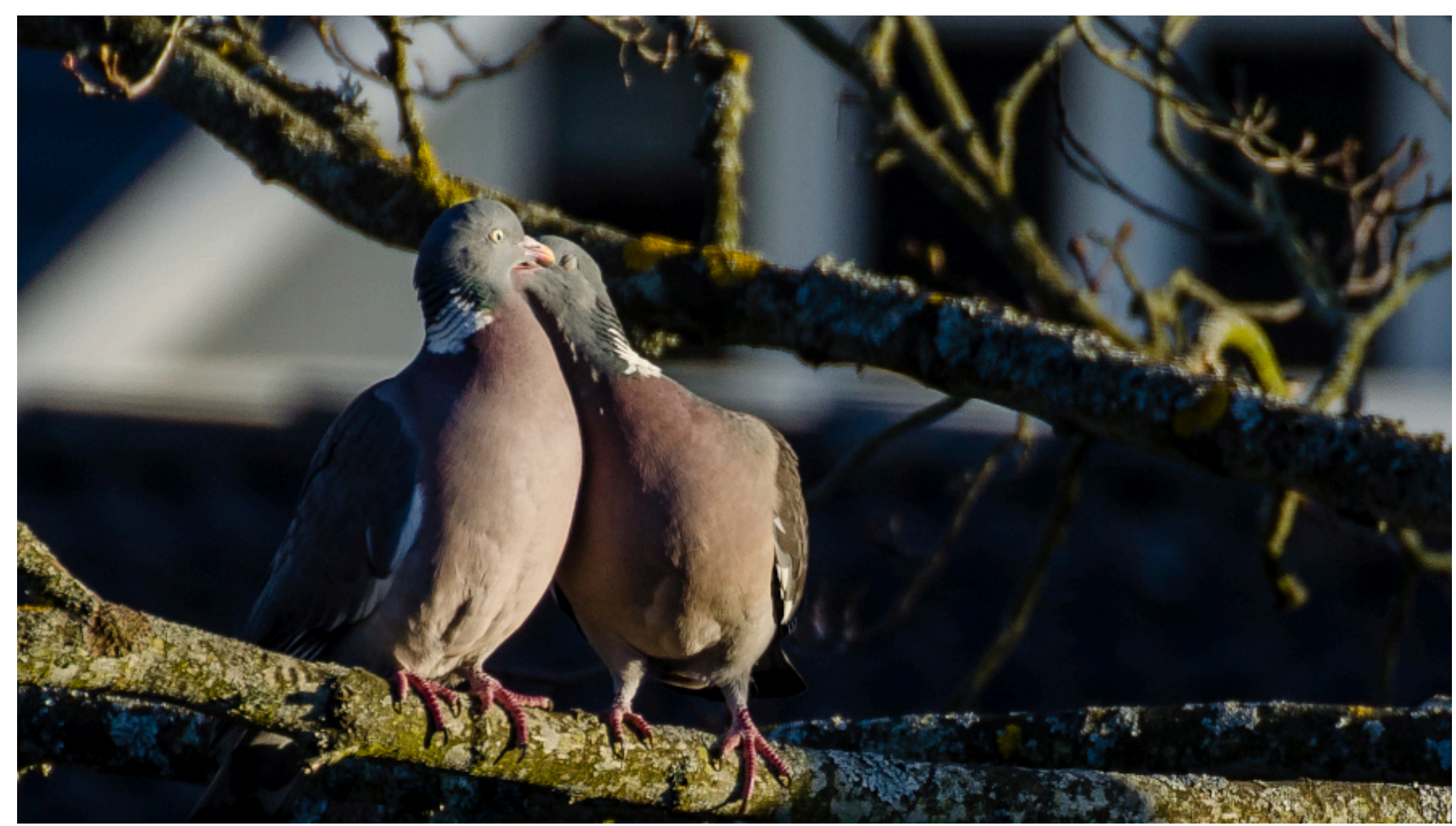

Figur 1. Skolans undervisning i biologi riskerar att förstärka föreställningar och normer i samhället om vad som är "naturligt" när det gäller sexualitet, manlighet och kvinnlighet.

\section{Elever gör kopplingar mellan djur och människor efter lektion}


Resultaten visar på problem som kan uppstå när lärare och böcker utgår från djurvärlden under en lektion om sexualitet och relationer. Det kan bland annat leda till att undervisningen förmedlar en bild av att sexualitet främst handlar om reproduktion och att manlighet och kvinnlighet är varandras motsatser.

Det visade sig att eleverna vid slutet av lektionen kunde beskriva tydliga kopplingar mellan djurs och människors sexuella beteende. Likheter som eleverna lyfte fram mellan djur och människor rörde till exempel kvinnors underordning, betydelsen av utseende och yttre attribut samt att stora materiella tillgångar gör en man attraktiv. Vissa elever verkade dock ta avstånd från jämförelser som kom fram i undervisningssituationen som de inte tyckte stämde in på dem själva.

\section{Biologin i fokus vid lektion om sex och relationer}

Forskaren har analyserat en inspelad lektion i naturkunskap om sexualitet och relationer i årskurs ett på det samhällsvetenskapliga programmet, samt intervjuer med läraren och 13 av klassens 32 elever. Under lektionen gick läraren igenom djurs sexuella beteenden. Sedan fick eleverna diskutera om det finns kopplingar mellan sex i djurvärlden och människors sexualitet och sexuella handlingar. Lärarens syfte med det var att biologiska aspekter av människans sexualitet skulle hamna i fokus. Därmed skulle innehållet bli mindre känsligt för eleverna i och med att de inte behövde blotta sina egna känslor och erfarenheter.

Resultaten visar att läraren använde sig mycket av antropomorfism, vilket innebär att djur ges människoliknande egenskaper. Till exempel inledde läraren lektionen med att läsa upp en berättelse om en honungsgök som är orolig för att honorna vill ha sex med honom bara för att få äta av hans förråd av bivax.

I genomgången kopplade läraren också ihop manlighet och kvinnlighet med sex och lyfte fram reproduktion som målet med både djurs och människors sexuella aktivitet. Även om de bilder som läraren förmedlade av manligt och kvinnligt i djurvärlden inte var entydiga så beskrevs de som ett motsatspar. Det som honor gör beskrevs som kvinnligt beteende och det som hanar gör beskrevs som manligt beteende. Skillnader mellan könen blev därmed det som stod i fokus.

\section{Viktigt variera beskrivningar av manligt och kvinnligt}

De beskrivningar av manligt och kvinnligt som läraren använde under lektionen har stora likheter med beskrivningar som är vanliga i läroböcker i biologi. Trots att exempel från djurriket skulle kunna användas för att belysa den mångfald och variation som finns i sexuella beteenden så har studier visat att biologiböcker för gymnasiet ofta ger en stereotyp bild av djurs sexuella beteende. Precis som under lektionen så beskriver böckerna ofta manliga och kvinnliga egenskaper som ett motsatspar och reproduktion som målet med sexuell aktivitet. Forskaren skriver att det därför finns en risk att biologin legitimerar eller till och med förstärker föreställningar och normer i samhället om vad som är "naturligt" när det gäller sexualitet, manlighet och kvinnlighet. Vid diskussioner om människans sexualitet kan det alltså finnas särskild anledning att förhålla sig kritisk till läroböckernas innehåll.

För att inte undervisningen ska upprätthålla och förstärka oönskade normer menar forskaren att lärare måste sträva efter att lyfta fram varierande beskrivningar av manligt och kvinnligt. Lärare måste våga problematisera och presentera alternativ till de bilder av kön och sexualitet som är dominerande. Forskaren föreslår till exempel att lärare försöker prata om sexualitet utan koppling till reproduktion. Ett annat sätt att utmana dominerande föreställningar skulle kunna vara att låta eleverna diskutera om det är möjligt och lämpligt att använda djurs sexuella beteenden som utgångspunkt för att dra slutsatser om människors sexualitet och relationer.

\section{Lärarpanel}




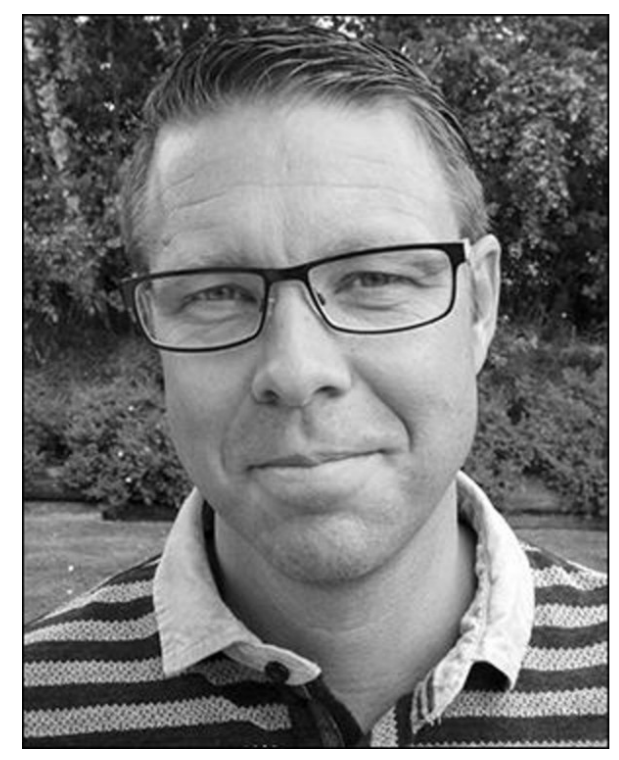

Figur 2. Robert Andersson, NATDID:s lärarpanel.

Robert Andersson är gymnasielärare och undervisar i naturkunskap, biologi och bioteknik på Alléskolan i Hallsberg (Figur 2). Han känner igen sig i stora delar av det som beskrivs i artikeln från undervisningen inom området sex och relationer på den skola där han arbetar.

- Vi brukar också delge biologiska förklaringsmodeller kring reproduktion hos olika organismer, säger Robert.

Däremot menar Robert att de läromedel de använder på hans skola inte är så stereotypa som artikeln lyfter fram att biologiböcker ofta är. När Gy 11 infördes kom området sex och relationer att ingå i ämnena naturkunskap och biologi. I samband med det valde de på hans skola läromedel som anpassat sitt innehåll efter det nya centrala innehållet, till exempel när det gäller frågor om normer eller sexuell läggning.

- Eftersom området inte ingick tidigare behövde de flesta lärare också utveckla sin ämneskompetens, berättar Robert. Flera i ämnesgruppen har fortbildat sig via veckokurser anordnade av RFSU och under åren har vi utvecklat en del gemensamma aktiviteter och förhållningssätt.

- Till exempel är vi mycket måna om att avliva myten om mödomshinnan, fortsätter han. Det är inte enkelt att undervisa om oskuld, som kan vara ett tabubelagt ämne för vissa elever, men vi har bland annat använt oss av en film från UR, "Myten om mödomshinnan", följt av en diskussion. Filmen har många perspektiv som problematiserar synen på sex och relationer, till exempel synen på oskuld inom islam idag, men också hur man såg på flickors oskuld i Sverige för inte så länge sedan.

En viktig sak som alla som undervisar om sex och relationer kan ta med sig från artikeln är att prata om sexualitet utan koppling till reproduktion, menar Robert. Det är också viktigt att vara observant på vilka exempel på sexuella beteenden som ges i läroböcker och av läraren. Detta gäller inte minst om syftet är att diskutera begrepp som till exempel hetero-, homo- och bisexualitet genom jämförelser med djurs beteenden. Det är viktigt att se djurexemplen som just exempel på variation och mångfald och på samma sätt ge exempel på variation hos människor i fråga om kön och sexuell läggning.

Robert tar också med sig en ökad insikt om att skolans undervisning om sex och relationer kan påverka elevens utveckling av sin självbild, till exempel i fråga om vad som är manligt och kvinnligt. 
- Undervisningen har mest syftat till att öka acceptansen och förståelsen för olika sexuell läggning samt vikten av att använda preventivmedel i syfte att förhindra spridning av könssjukdomar.

Efter att ha läst artikeln fick Robert inspiration till en examinationsuppgift för sina elever i Biologi 2. Eleverna fick diskutera vilka för- och nackdelar det kan finnas med att jämföra människors sexuella beteende med andra djurs. Han tycker att frågan var bra på så sätt att svaren synliggjorde hur eleverna tolkade några av de exempel som hade använts i undervisningen.

\section{Notering}

Denna text har tidigare publicerats på Linköpings universitets hemsida.

\section{Referenser}

1. Orlander AA. 'So, what do men and women want? Is it any different from what animals want?' Sex education in an upper secondary school. Research in Science Education. $2015 ; 46(6)$ 